\title{
Photoredox-Catalyzed Decarboxylative Alkynylation of Peptides
}

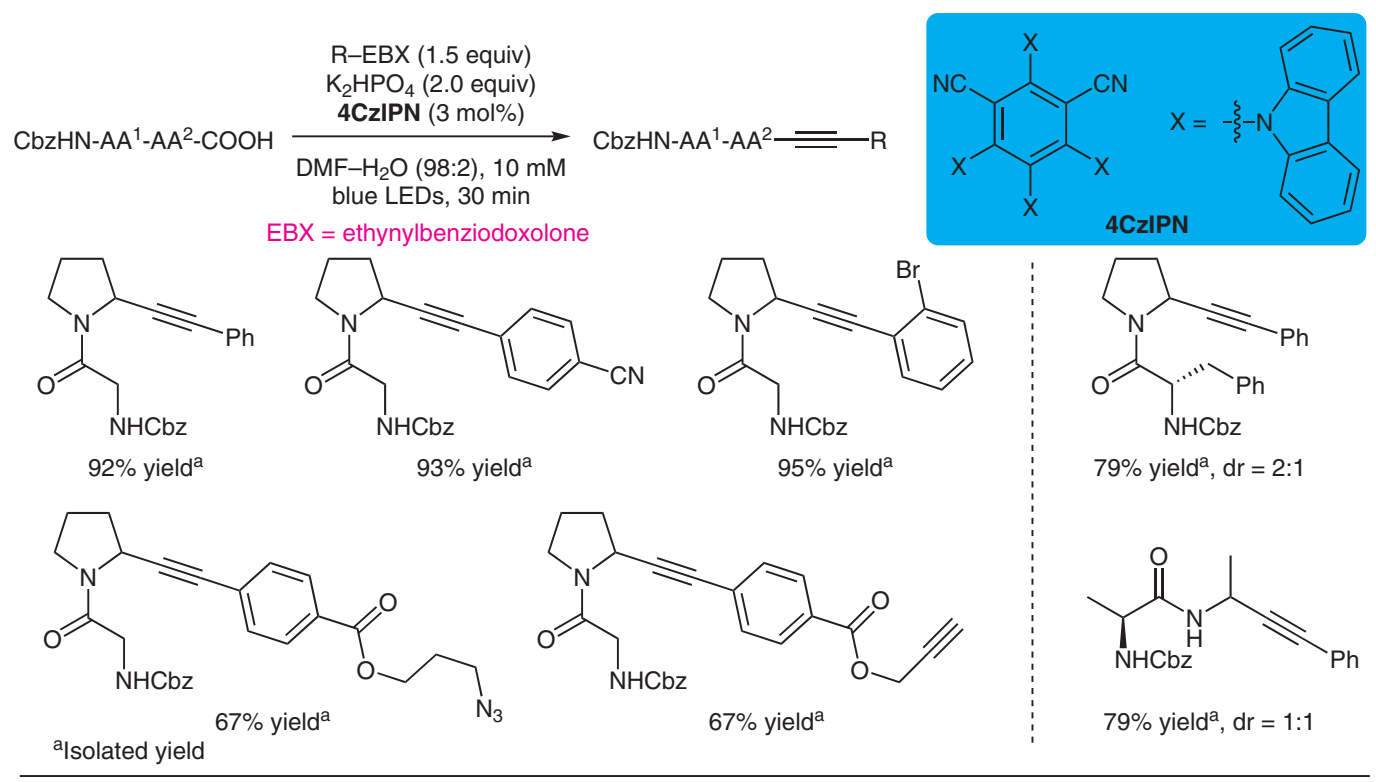

$$
\begin{aligned}
& \text { AcHN-AA }{ }^{1} \text {-Phe-Gly-Pro }=P h
\end{aligned}
$$

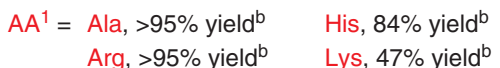

$$
\begin{aligned}
& \mathrm{S}-\mathrm{Ph} \quad>95 \% \text { yield }^{\mathrm{b}} \\
& \text { AcHN-Cys-Phe-Gly-Pro } \stackrel{\text { - }}{=} \mathrm{Ph}
\end{aligned}
$$$$
67 \% \text { yield }^{a}
$$

$\mathrm{Ph}-\mathrm{EBX}$ (3.0 equiv) $\mathrm{K}_{2} \mathrm{HPO}_{4}$ (10.0 equiv) 4CzIPN (30 mol\%)

$$
\overrightarrow{D M F-H_{2} \mathrm{O}(95: 5), 10 \mathrm{mM}}
$$

$\mathrm{ACHN}-A A^{1}-A A^{2}-A A^{3}-A A^{4}=P h$ blue LEDs, $30 \mathrm{~min}$

B) Scope at the C-terminus

$$
\begin{aligned}
& \text { AcHN-Ala-Phe-Gly-AA }{ }^{4}=P h \\
& \mathrm{AA}^{4}=\text { Ala },>95 \% \text { yield }^{\mathrm{b}} \quad \text { Gly, }>95 \% \text { yield }^{\mathrm{b}} \\
& \text { Phe, }>95 \% \text { yield }^{\mathrm{b}} \quad \text { Glu, }>95 \% \text { yield }^{\mathrm{b}} \\
& \text { Ser, }>95 \% \text { yield }^{b} \quad \text { His, } 76 \% \text { yield }^{b} \\
& \text { Met, }>95 \% \text { yield }^{\mathrm{b}} \quad \text { Asp, } 37 \% \text { yield }^{\mathrm{b}}
\end{aligned}
$$

\section{Key words}

photoredox catalysis

decarboxylation

alkynylation

C-terminal

selectivity

hypervalent iodine

reagents

metal-free

C) Internal selectivity: C-terminus vs side chain

$$
\begin{aligned}
& \text { AcHN-AA }{ }^{1}-\text { Phe-Gly-AA } A^{4}=\mathrm{Ph} \\
& A A^{1}=\text { Asp, } A A^{4}=\begin{array}{l}
\text { Pro, }>95 \% \text { yield } \\
\text { Ala },>95 \% \text { yield } \\
\text { Gly, } 48 \% \text { yield }
\end{array} \quad \quad A A^{1}=\text { Glu, } A A^{4}=\begin{array}{l}
\text { Pro, }>95 \% \text { yield }^{b} \\
\text { Gly, } 75 \% \text { yield }^{b}
\end{array}
\end{aligned}
$$

bYield measured by HPLC as the ratio of the area of the product over remaining starting material and possible side products at $214 \mathrm{~nm}$

Significance: This paper provides a decarboxylative strategy for the alkynylation of the C-terminus of peptides, starting from free carboxylic acids. C-Terminal selectivity can be achieved in the presence of carboxylic acid side chains, and a broad range of functional groups are tolerated in the reaction system.
Comment: The authors have developed a metalfree decarboxylative alkynylation of the $\mathrm{C}$-terminus of peptides. The reaction proceeds rapidly and cleanly and might be useful for modifying peptides. 